\title{
Effect of osmotic stress on in vitro translational capacity of polysomes and on the composition of polysome-associated proteins in germinating seeds of pea (Pisum sativum L.)
}

\author{
Wioletta Brosowska-Arendt*, Stanisław Weidner \\ Department of Biochemistry, University of Warmia and Mazury in Olsztyn, Oczapowskiego 2, 10-719 Olsztyn, Poland
}

\section{Abstract}

Plant growth throughout the world is often limited by unfavourable environmental conditions. This paper reports results of a study on long- and short-term osmotic stress $(-0.5 \mathrm{MPa})$ followed by a recovery on in vitro translational capacity of polysomes and on the composition of polysome-associated proteins in germinating pea (Pisum sativum L.) seeds. Here we show that, under osmotic stress, cytoskeleton-bound polysomes were charaterized by the highest translation activity, which may be indicative of an important role that this population of polysomes plays in the synthesis of the so-called "stress proteins". We also find out that in response to osmotic stress, new proteins $(22.01,96.47$ and $105.3 \mathrm{kDa})$, absent in the unstressed sample, associated with the total pool of polysomes, whereas the protein of $22.95 \mathrm{kDa}$, which was present in the embryonic tissue of seeds germinating under unstressed conditions, disappeared. These changes may have affected both the stability and the translational capacity of polysomes.

Keywords: germinating, osmotic stress, pea seeds, polyethylene glycol, polysomes, ribonuclease, translation in vitro

\section{Introduction}

Changes in the environment, such as drought, salinity, high or low temperature, are an important factor which affects the growth of crops and the volume of crop yields [1-3]. Very important legume grown and consumed extensively worldwide is pea [4]. As a rich source of proteins, carbohydrates, fibre, vitamins and minerals, peas are important in human nutrition [5]. Pea is the fourth leading legume in terms of consumption in the world after soybean, peanuts and bean [6]. One of the major abiotic stress often occurs in Europe is osmotic stresses induced with polyethylene glycol (within -0.5 $\mathrm{MPa}$ ). The earliest metabolic change caused by water stress is a decreased amount of polysomes [7]. Once the polysomes have been disaggregated, the plant growth is inhibited due to a slower protein synthesis rate [7-9]. Considerable reduction in the amount of polysomes in plant tissues is observable after osmotic stress lasting for just 20-30 minutes [10]. Decrease of the content of polysomes in response to abiotic stresses is connected with the process of "switching" the expression of genes from those participating in the growth and development

*Corresponding author. Email: wioletta.brosowska@uwm.edu.pl

This is an Open Access digital version of the article distributed under the terms of the Creative Commons Attribution 3.0 License (creativecommons.org/licenses/by/3.0/), which permits redistribution, commercial and non-commercial, provided that the article is properly cited. of plants under unstressed conditions to the ones active in response to stress [11].

In plant tissues, polysomes can occur as free polysomes (FP), endoplasmic reticulum membrane-bound polysomes (MBP) [12], cytoskeleton-bound polysomes (CBP) [13,14] and cytoskeleton-membrane-bound polysomes (CMBP) [15]. Changes in the distribution of polysomes between the particular fractions reflect changes in the complement of proteins, as each population of polysomes is engaged in the synthesis of specific proteins [16]. Thus, the FP population is mainly involved in the synthesis of soluble proteins of the cytoplasm, cellular nucleus, mitochondria and peroxisomes [17]; the MBP population is engaged in the production of secretory proteins, lysosome proteins and the proteins which are an integral component of the plasmatic membrane and intracellular membranes, including the endoplasmic reticulum [16,17]; finally, the CBP and CMBP populations are responsible for the synthesis of cytoskeleton and stress proteins [16,18-21]. The largest share in the total polysome pool consists of the CBP population, which sometimes reaches $70 \%$ of the total polysome content [22]. Polysomes contain mRNAs, which may undergo selective translation, result in modification of protein synthesis in response to stress conditions in plants $[23,24]$.

The objective of this study was to indicate differences in the composition of polysome-bound proteins and in the products of in vitro translation in pea (Pisum sativum L.) seeds germinating under unstressed conditions and under long- and short-term osmotic stress $(-0.5 \mathrm{MPa})$ followed by post-stress recovery. 


\section{Material and methods}

\section{Plant material and germination under normal and osmotic stress conditions}

The experiments were conducted on Pisum sativum L. cv. six-week TOR seeds, supplied by Torseed S.A. (Toruń, Poland). Seeds were surfaced disinfected in $1 \%$ sodium hypochloride for 3 minutes and washed with tap water and sterile water. Disinfected and intact seeds were placed on Petri dishes with two layers of Whatman 2 filter paper No. 1 (Whatman, Maidstone, Kent, the UK) wetted with $40 \mathrm{ml}$ distilled water and germinated in the dark at $20^{\circ} \mathrm{C}$ for 48 (C48), 72 (C72) and 96 hours (C96). After 48 hours, some seeds germinated under unstressed conditions (distilled water), whose roots were $\geq 1 \mathrm{~mm}$, were transferred for next $24 \mathrm{~h}$ to osmotic stress conditions with polyethylene glycol (PEG), which caused decrease of water potential to $-0.5 \mathrm{MPa}(\mathrm{S} 72 ; 48 \mathrm{~h}$ distilled water $+24 \mathrm{~h}$ osmotic stress). After short-term osmotic stress, early seedlings of pea were transferred again to unstressed germination conditions for another 24 hours - recovery (SR96; $48 \mathrm{~h}$ distilled water +24 $\mathrm{h}$ osmotic stress $+24 \mathrm{~h}$ distilled water). At the same time, other pea seeds were germinated under long-term osmotic stress conditions $(-0.5 \mathrm{MPa})$ at $20^{\circ} \mathrm{C}$ for 96 hours (S96). Having fixed the time of germination, sprouts or early seedlings (according to Gong et al. [25]) were isolated from seeds and used for further tests. All determinations were repeated three times.

\section{Polysome isolation}

The tissue (400 mg) was homogenized in $3 \mathrm{ml}$ of cytoskeleton-stabilizing buffer $\mathrm{C}$ [22], filtered and centrifuged at $27000 \times g$ for $10 \mathrm{~min}$. Buffer $\mathrm{C}$ consist of $5 \mathrm{mM}$ HEPES (N-2-hydroxyethylpiperazine- $\mathrm{N}^{\prime \prime}$-2-ethanesulfonic acid), 10 $\mathrm{mM} \mathrm{Mg}(\mathrm{OAc})_{2}$ (magnesium acetate), 2 mM EGTA [ethylene glycol-bis (aminoethyl ether) N,N,N",N"-tetraacetic acid], 1 mM PMSF (phenylmethylsulfonyl fluoride) adjusted to $\mathrm{pH}$ 7.5 with $9.8 \mathrm{mM} \mathrm{KOH}$. This buffer allows sequential isolation of four polysome populations [26]: FP, MBP, CBP and CMBP. The supernatant polysomes included FP and, to prevent their degradation by RNAse, the samples were adjusted to buffer $\mathrm{U}$, consisting of $200 \mathrm{mM}$ Tris- $\mathrm{HCl}, \mathrm{pH} 8.5,50 \mathrm{mM} \mathrm{KOAc}$ (potassium acetate), $25 \mathrm{mM} \mathrm{Mg}(\mathrm{OAc})_{2}, 2 \mathrm{mM}$ EGTA, 100 $\mathrm{mg} / \mathrm{ml}$ heparin, 2\% PTE (polyoxyethylene-10-tridecyl ether, a non-ionic detergent) and $1 \%$ DOC (sodium deoxycholate) [27] by adding $1 / 4$ vol. of $4 \times$ concentrated of buffer $U$ and held on ice prior to further processing. The remaining polysomes were in the pellet and were sequentially solubilized as followed. The pellet was resuspended in $3 \mathrm{ml}$ of buffer $\mathrm{C}+0.5 \%$ PTE to disrupt membranes, centrifuged for $10 \mathrm{~min}$ at $27000 \times g$ to leave MBP in the supernatant (again converted to buffer $U$ to maintain polysome integrity). All the other polysomes were still in the pellet. This pellet was next resuspended in $3 \mathrm{ml}$ of buffer $\mathrm{C}+200 \mathrm{mM}$ Tris- $\mathrm{HCl}, \mathrm{pH} 8.5$ to disrupt the polysomecytoskeleton interaction and centrifuged for $10 \mathrm{~min}$ at $27000 \times$ $g$ to leave CBP in the supernatant (again converted to buffer $U$ ). The final pellet was resuspended in $4 \mathrm{ml}$ of $1 \times$ concentrated of buffer $U$ and re-centrifuged to release CMBP. All supernatant fractions (FP, MBP, CBP, CMBP) were layered on a $0.5 \mathrm{ml}$ "pad" of $50 \%(\mathrm{w} / \mathrm{v})$ sucrose in buffer B [ $50 \mathrm{mM}$ Tris- $\mathrm{HCl}, \mathrm{pH}$ 7.5, 20 $\mathrm{mM} \mathrm{KOAc}, 10 \mathrm{mM} \mathrm{Mg}(\mathrm{OAc})_{2}$ ] and centrifuged for $90 \mathrm{~min}$ at $300000 \times g$ in Beckman 65 Ti rotor. Sprouts or early seedlings of pea were also homogenized in buffer $U$ [27] to solubilize total polysomes.

\section{Polysomes protein separation with the Laemmli method}

The content of protein was determined using Bradford's method [28]. The polysome pellets were resuspended in 0.15 $\mathrm{ml}$ of lysis buffer, consisting of $0.125 \mathrm{M}$ Tris- $\mathrm{HCl} \mathrm{pH} \mathrm{6.8,} \mathrm{4 \%}$ SDS, $10 \%$ 2-merkaptoethanol, $20 \%$ glycerol and $0.05 \%$ bromophenol blue. The resuspended polysomes were boiled at $95^{\circ} \mathrm{C}$ for $4 \mathrm{~min}$ and centrifuged at $27000 \times \mathrm{g}$ for $3 \mathrm{~min}$, after which they were cooled to $0-4^{\circ} \mathrm{C}$.

Proteins connected with the total polysome pool and with particular polysome fractions were separated in 12\% SDSPAGE on an electrophoretic apparatus Mini-PROTEAN GEL II (Bio-Rad). Each time, $40 \mu \mathrm{g}$ of protein was applied to each lane. Electrophoresis was run for $45 \mathrm{~min}$ at the temperature of $0-4^{\circ} \mathrm{C}$ and $200 \mathrm{~V}$, using electrode buffer containing: $0.025 \mathrm{M}$ Tris- $\mathrm{HCl} \mathrm{pH} 3,0.192 \mathrm{M}$ glicyne and 1\% SDS. The gels were fixed in $5 \%$ solution of trichloroacetic acid (TCA) for $30 \mathrm{~min}$, then stained for $90 \mathrm{~min}$ with Coomassie Blue according to Laemmli [29], consisting of $0.1 \%$ Coomassie Blue R-250, 40\% methanole and 10\% acetic acid. When the protein had been stained, the gels were destained using a solution containing $25 \%$ of methanol and $10 \%$ of acetic acid. The gels were scanned with the Labscan 5.0, using an Image Scanner (Amersham). For the analysis of the gels, ScanGel 1.0 (Kucharczyk) was used.

\section{Electrophoresis and Western Blotting of in vitro synthesized proteins}

Sediments of the total ribosomal fraction and of particular populations of polysomes, i.e. FP, MBP, CBP and CMBP were dissolved in $0.05 \mathrm{ml}$ of $0.5 \%$ PTE solution and centrifuged. For each sample, optical density $(O D)$ was determined at the wavelengths of 260 and $330 \mathrm{~nm}$. The difference between the result at $330 \mathrm{~nm}$ and the one at $260 \mathrm{~nm}$ was the value of the $O D$ of a given sample. For an in vitro translation reaction, 2.0 $O D$ of polysomes were needed.

Polysomes $(2.0 \mathrm{OD})$ were mixed with the components of a translation mixture according to the instruction attached to the "Rabbit Reticulocyte Lysate System" (Promega), incubated at $30^{\circ} \mathrm{C}$ for $90 \mathrm{~min}$, and then mixtures were placed on ice to stop the reaction. The content of a protein was established with Bradford's method [28]. The reagent mixture was dissolved in a lysing reagent (the contents as above) in a 1:4 ratio, heated at the temperature of $95^{\circ} \mathrm{C}$ for $4 \mathrm{~min}$, centrifuged at $27000 \times g$ for 3 minutes and chilled to $0-4^{\circ} \mathrm{C}$. The biotinylated proteins were separated in $12 \%$ SDS-PAGE according to Laemmli [29]. $20 \mu \mathrm{g}$ of the protein was applied to each lane. The control sample, with which it was possible to eliminate the so-called background effect, contained all the components of the translation mixture (except polysomes) as well as the luciferase RNA standard.

The biotinylated proteins separated by electrophoresis transferred to polyvinylidene difluoride membrane (PVDF; Immobilon-P of the pore diameter equal $0.45 \mu \mathrm{m}$; Millipore). The electrotransfer was conducted at fixed voltage of $100 \mathrm{~V}$ for $60 \mathrm{~min}$ at $15-20^{\circ} \mathrm{C}$. The buffer for the transfer contained $25 \mathrm{mM}$ Tris, $192 \mathrm{mM}$ glicyne, 20\% methanole, 0.1\% SDS. Afterwards, biotinylated proteins were visualized by binding Streptavidin-HRP, followed by chemiluminescent detection (Transcend $^{\mathrm{TM}}$ Chemiluminescent Translation Detection System; Promega) and scanned using Labscan 5.0 software on an ImageScanner (Amersham). To determine the apparent weight of the translated biotinylated proteins, biotinylated protein standards (Bio-Rad) were used. For analysis, ScanGel 1.0 (Kucharczyk) was run. 


\section{Results}

SDS-PAGE showed that small-molecule proteins - less than $40 \mathrm{kDa}$ (Fig. 1) - dominated among the ribosomal proteins bound with the total population of polysomes as well as with their particular fractions, such as FP, MBP, CBP and CMBP. In the profile of polysomal proteins isolated from early pea seedlings grown under unstressed conditions and under long-term osmotic stress $(-0.5 \mathrm{MPa})$, obtained after 96 hours of seed germination, qualitative and quantitative changes were observed. It was found out that in response to the osmotic stress the 22.0, 96.5 and $105.3 \mathrm{kDa}$ proteins, absent in the control samples, bound with the total population of polysomes. It is noteworthy that these proteins $(22.0$ and $105.3 \mathrm{kDa})$ also bound to all fractions of polysomes (FP, MBP, CBP and CMBP) isolated from seeds germinated under stress conditions. Besides, in response to stress conditions, plants produced such proteins that bound to specific polysomal fractions, e.g. the $50.3 \mathrm{kDa}$ protein which bound to the FP population, $58.9 \mathrm{kDa}$ - to CMBP, and 101.4 $\mathrm{kDa}$ - to $\mathrm{FP}, \mathrm{CBP}$ and CMBP. In turn the $23.0 \mathrm{kDa}$ protein, which was present in pea seeds germinating under unstressed conditions, under osmotic stress was absent, both from the total polysomal population and from any of the polysomal fractions (Fig. 1). Furthermore, it was also observed that under the effect of water stress, the amounts of 23.5, 24.9, 50.3, 58.9 and $110.0 \mathrm{kDa}$ proteins bound with the total population of polysomes increased in comparison with the control (Fig. 1). Some other proteins of the particular polysomal populations formed during the water stress of $-0.5 \mathrm{MPa}$ also occurred in either larger or smaller quantities than in the control. The proteins bound with MBP were observed in smaller amounts while the ones bound with FP increased (Tab. 1).

In vitro translation primed by total polysomes and their particular fractions (FP, MBP, CBP and CMBP) indicated that there were differences in the newly synthesised proteins, both during the seed germination under the unstressed conditions and between the control sample versus the samples treated with osmotic stress. These differnces were both quantitative and qualitative. During the germination under the unstressed conditions, the in vitro synthesis of 108.2 and $158.3 \mathrm{kDa}$ proteins decreased, while that of 20.7 and $21.9 \mathrm{kDa}$ proteins increased (Fig. 2). Under the effect of both long- and shortterm osmotic stress (S96, S72), the 20.7, 21.9, 26.6, 108.2 and $158.3 \mathrm{kDa}$ proteins were observed to be synthesized more effectively, and therefore appeared in larger quantities than under the unstressed conditions (C96, C72, respectively). However, during the recovery after the short-term osmotic stress (SR96), the synthsis of these proteins decreased in comparison with the sample exposed to the stress (S72).

With respect to in vitro translation which involved particular populations of polysomes isolated from 96-hour pea seedlings grown under the unstressed conditions and under long-term water stress of the intensity of $-0.5 \mathrm{MPa}$, differences were mainly observed between the 108.2 and $158.3 \mathrm{kDa}$ proteins. In pea seedlings grown under the unstressed conditions, the $108.2 \mathrm{kDa}$ protein was synthesized mainly by the MBP as well as $\mathrm{CBP}$ and CMBP fractions, while the $158.3 \mathrm{kDa}$ protein - by the FP, MBP, CBP populations and, only weakly, by CMBP. For comparison, in pea seedlings growing under long-term osmotic stress, the $108.2 \mathrm{kDa}$ protein was synthesized in vitro mainly by the MBP and CBP populations and, to a smaller extent, by the $\mathrm{FP}$ and CMBP fractions, while the $158.3 \mathrm{kDa}$ protein - by the $\mathrm{MBP}$ and $\mathrm{CBP}$ populations. It was also demonstrated that the most important differences between the osmotic stress and control samples appeared in the proteins which were synthesized on the CBP population. In response to the stress conditions, these proteins $(>66 \mathrm{kDa})$ were more intensively synthesized than under the unstressed conditions (Fig. 3).

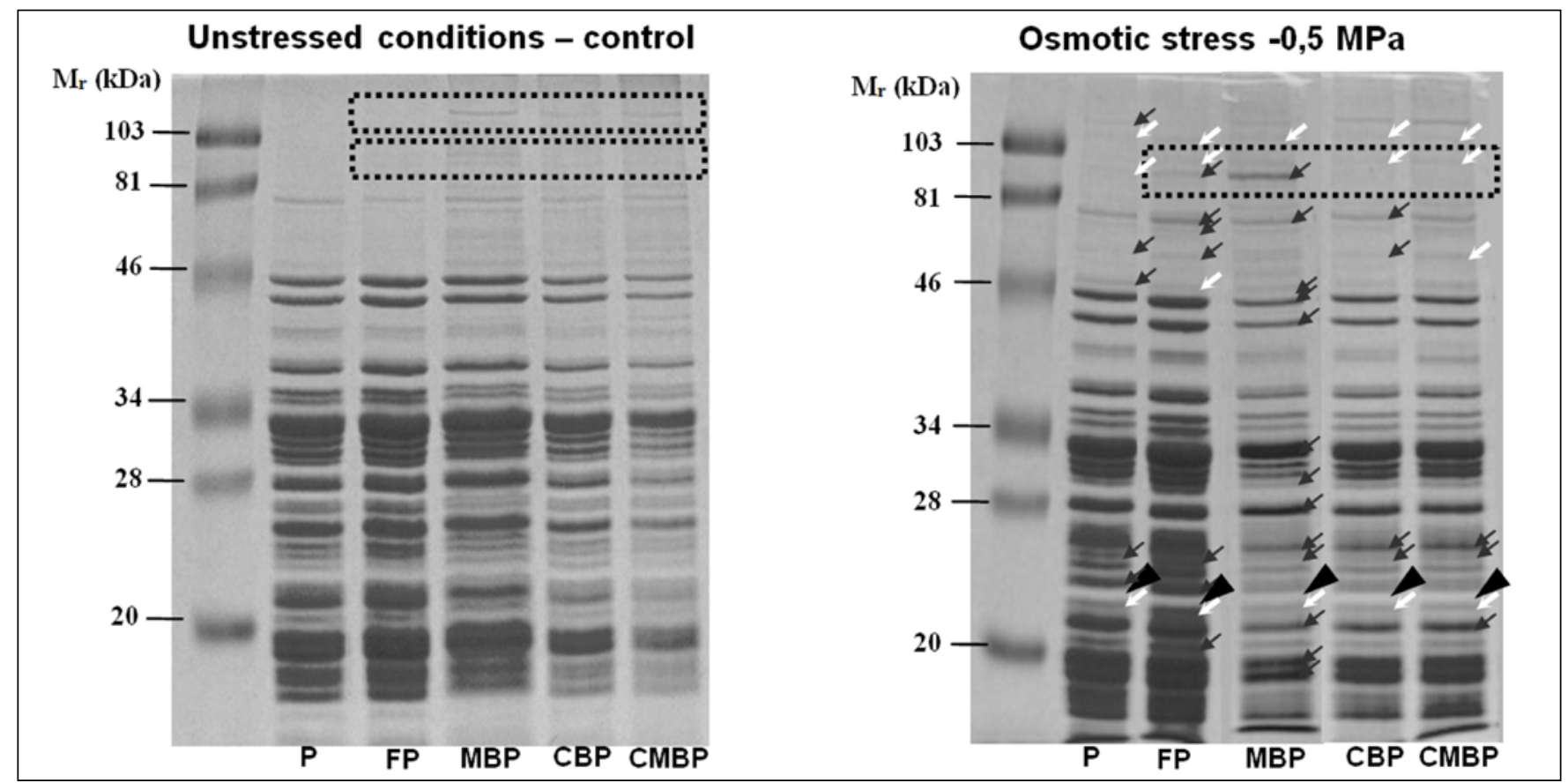

Fig. 1 SDS-PAGE of proteins bound to the total polysomal population and to particular polysomal fractions: FP, MBP, CBP and CMBP, isolated from embryonic tissue after $96 \mathrm{~h}$ of pea seed germination under unstressed (control) and long-term osmotic stress $(-0.5 \mathrm{MPa})$ conditions. Molecular weight $(\mathrm{kDa})$ of protein markers are given to the left. Black arrowheads - proteins which were absent under stress conditions; black frames - differences between proteins within a given sample; grey arrows - proteins different in quantities between control and stress samples; white arrowheads - proteins which were joined to polysomes during stress. $\mathrm{P}$ - total polysomal population. 
Tab. 1 Differences in proteins associated with the total population of polysomes and with their particular fractions: FP, MBP, CBP, CMBP, isolated from embryonic tissue after $96 \mathrm{~h}$ of germination under unstressed (control) and long-term osmotic stress ( $-0.5 \mathrm{MPa})$ conditions.

\begin{tabular}{|c|c|c|c|c|c|c|c|c|c|c|}
\hline \multirow[b]{2}{*}{ Protein $(\mathrm{kDa})$} & \multicolumn{4}{|c|}{ Control } & & \multicolumn{5}{|c|}{ Osmotic stress $-0.5 \mathrm{MPa}$} \\
\hline & $\mathbf{P}$ & FP & MBP & CBP & CMBP & $\mathbf{P}$ & FP & MBP & CBP & CMBP \\
\hline 110.0 & + & + & + & + & + & $\pi$ & + & + & + & + \\
\hline 105.3 & - & - & - & - & - & + & + & + & + & + \\
\hline 101.4 & + & - & + & - & - & + & + & + & + & + \\
\hline 96.5 & - & + & + & + & + & + & $\pi$ & $\pi$ & + & + \\
\hline 77.8 & + & + & + & + & + & + & $\pi$ & $\pi$ & $\pi$ & + \\
\hline 67.4 & + & + & + & + & + & + & $k$ & + & + & + \\
\hline 58.9 & + & + & + & + & - & $\pi$ & $\pi$ & + & $\pi$ & + \\
\hline 50.3 & + & - & + & + & + & $\pi$ & + & $k$ & + & + \\
\hline 46.1 & + & + & + & + & + & + & + & $k$ & + & + \\
\hline 32.0 & + & + & + & + & + & + & + & $k$ & + & + \\
\hline 28.0 & + & + & + & + & + & + & + & $k$ & + & + \\
\hline 25.0 & + & + & + & + & + & + & + & $k$ & $\pi$ & $\pi$ \\
\hline 24.9 & + & + & + & + & + & $\pi$ & $\pi$ & $k$ & $k$ & $k$ \\
\hline 23.5 & + & + & + & + & + & $\pi$ & $\pi$ & + & + & + \\
\hline 22.9 & + & + & + & + & + & - & - & - & - & - \\
\hline 22.0 & - & - & - & - & - & + & + & + & + & + \\
\hline 20.2 & + & + & + & + & + & + & + & $k$ & + & $\pi$ \\
\hline 19.9 & + & + & + & + & + & + & $\pi$ & + & + & + \\
\hline 18.3 & + & + & + & + & + & + & + & $k$ & + & + \\
\hline 17.3 & + & + & + & + & + & + & + & $k$ & + & + \\
\hline
\end{tabular}

“+” - presence; “-” - absence; “ $\lambda$ ” - increased; “ or particular polysomal fractions in an experimental sample.

\section{Discussion}

The PEG used in our experiments is a neutral polymer which binds water, thus simulating soil drought stress [30,31]. Scientific experiments which simulate naturally ocurring conditions enable us to expand our knowledge of a given environmental stress factor and plant reactions to this stress, thus making it possible to obtain crops which are more tolerant to a given stress factor.

Osmotic stress inhibits the process of seed germination and subsequent plant growth [32-37] as well as the process of polysome formation $[36,38,39]$. Changes in the profiles of polysomes, which contain mRNAs undergoing translation, enable us to follow very precisely the rate of in vivo synthesis of proteins in cells [40].

The changes in the composition of polysomal proteins presented in this paper may play an important role in the regulation of translation under stress conditions and can result in the differentiated translational activity of particular fractions of polysomes, which had been demonstrated earlier $[19,20,39,41,42]$. The end products from in vitro translation of polysomes also reflect the activity of mRNAs that respond to stress [43]. Synthesis of most proteins under environmental stresses is reduced but translation of individual mRNA species is differentially regulated [23,44-46]. Kawaguchi et al. [45] showed that less than $1 \%$ of the stress-induced mRNAs increased significantly in polysome association, what can suggest that proteins encoded by this mRNAs were synthesized at higher levels during stress conditions. In turn on Shenton et al. [47] suggested that under low intensity of oxidative stress

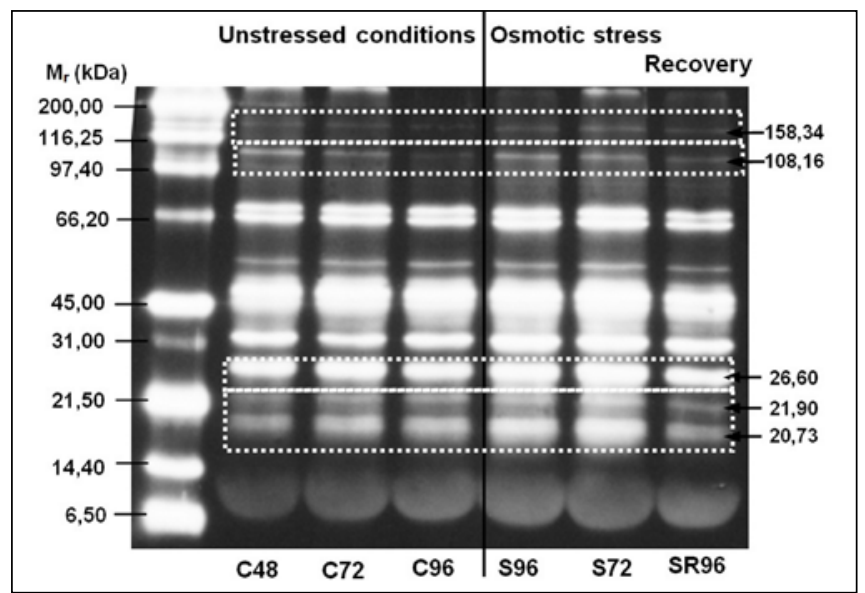

Fig. 2 Chemiluminescent detection of biotinylated proteins which were synthesized in vitro by total polysomal isolated from embryonic tissue of pea seeds germinated under unstressed conditions after $48 \mathrm{~h}$ (C48), 72 h (C72), 96 h (C96), under long-term (S96; 96 h osmotic stress) and short-term (S72; $48 \mathrm{~h}$ distilled water $+24 \mathrm{~h}$ osmotic stress) osmotic stress $(-0.5 \mathrm{MPa})$ and during recovery after short-term osmotic stress (SR96; $48 \mathrm{~h}$ distilled water $+24 \mathrm{~h}$ osmotic stress + $24 \mathrm{~h}$ distilled water) separated by SDS-PAGE. Biotinylated proteins were visualized by binding Streptavidin-HRP, followed by chemiluminescent detection. Differences between the proteins are presented in the boxes and the arrows indicate precisely these protein fractions. 


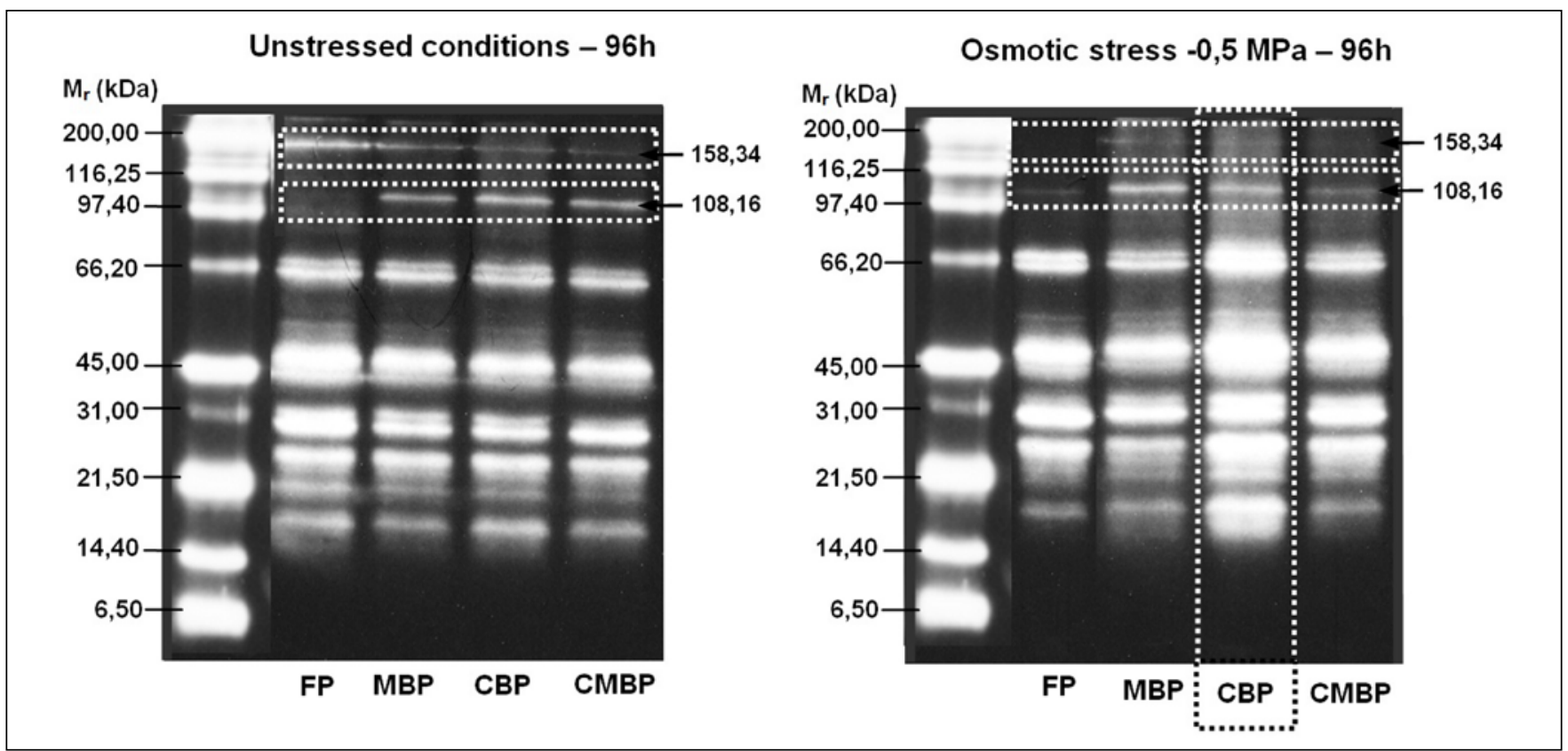

Fig. 3 Chemiluminescent detection of biotinylated proteins which were synthesized in vitro by particular polysomal fractions: FP, MBP, CBP and CMBP, isolated from embryonic tissue of pea seeds germinated under unstressed conditions (C96) and under long-term (S96) osmotic stress $(-0.5 \mathrm{MPa})$ separated by SDS-PAGE. Biotinylated proteins were visualized by binding Streptavidin-HRP, followed by chemiluminescent detection. Differences between the proteins are presented in the boxes and the arrows indicate precisely these protein fractions.

translation of stress protective proteins increased, whereas under high intensity - mRNAs increased in polyribosome association but translation activity does not increased. Under the influence of osmotic stress, in this study, some proteins were synthesized in vitro more intensively by the total population of polysomes than in the optimal conditions too. Higher translational activity of polysomes during cold acclimation of wheat seedlings and wounding of potato tubers, compared to the control conditions, was also observed by Perras and Sarhan [48] and Morelli et al. [49], respectively. The most important change was the more effectively synthesis of five polypeptides under stress, suggesting that their higher expression was associated with tolerance capacity to this stress. The expression of specific proteins during stress conditions may be determined by presence of IRES (internal ribosome entry site) at mRNAs 5' UTR region. Spriggs et al. [50] described that $10-15 \%$ of all mRNAs may be translated by IRES and there is coordinated translation of subsets IRESs during stress. This is probably alternative mechanisms of translation initiation selectively recruit mRNAs to polysomes during cell stress.

Davies et al. [19] described important role of the cytoskeleton in the translation process in plants. They suggested that initiation or elongation of the translation process, or else both of these stages, were faster on the cytoskeleton-bound polysomes (CBP and CMBP) than on polysomes not bound with the cytoskeleton (FP, MBP). Changes in translational activity may be determined by dynamics of the actin cytoskeleton. Depolimerization of actin filaments (e.g. under stress conditions) reduce translational activity, because components of the translational machinery (e.g. polysomes, initiation factors) are dispersed. In turn on, association of translational components with cytoskeleton may prevent diffusion of factors and thus increase translational activity [51]. The highest translational activity under water stress, in this study, was also demonstrated by the CBP. Higher translational activity of the CBP population than that of the FP or MBP fractions in bean tissues had been shown previously by Klyachko et al. [41]. Their results confirmed some subsequent findings reported by Weidner et al. [20], who observed that most of exogenous 14C-amino acids were incorporated, in the embryonic tissue of pea, in the newly formed polypeptide chain, synthesized with the CMBP population. They claimed that the CBP population may play an important role in the synthesis of the so-called stress proteins [20,21]. According to Kosowska et al. [36], there must be some mechanism of regulating translation which is activated in seeds germinating under osmotic stress that enables synthesis of specific proteins despite the total protein synthesis being reduced.

\section{References}

1. Howarth CJ, Ougham HJ. Gene expression under temperature stress. New Phytol. 1993;125(1):1-26. http://dx.doi. org/10.1111/j.1469-8137.1993.tb03862.x

2. Bhatnagar-Mathur P, Rao JS, Vadez V, Sharma KK. Transgenic strategies for improved drought tolerance in legumes of semi-arid tropics. JCRIP. 2009;24(1):92-111. http:// dx.doi.org/10.1080/15427520903337095

3. Szilagyi L. Influence of drought on seed yield components in common bean. Bulg J Plant Physiol. 2003; (special issue):320-330.

4. Gepts P. Legumes as a model plant family. Genomics for food and feed report of the cross-legume advances through genomics conference. Plant Physiol. 2005;137(4):12281235. http://dx.doi.org/10.1104/pp.105.060871

5. Urbano G, López-Jurado M, Frejnagel S, Gómez-Villalva E, Porres JM, Frías J, et al. Nutritional assessment of raw and germinated pea (Pisum sativum L.) protein and carbohydrate by in vitro and in vivo techniques. $\mathrm{Nu}-$ trition. 2005;21(2):230-239. http://dx.doi.org/10.1016/j. nut.2004.04.025

6. Vidal-Valverde C, Frias J, Hernandez A, Martin-Alvarez 
PJ, Sierra I, Rodriguez C, et al. Assessment of nutritional compounds and antinutritional factors in pea (Pisum sativum) seeds. J Sci Food Agric. 2003;83(4):298-306. http:// dx.doi.org/10.1002/jsfa.1309

7. Hsiao TC. Rapid changes in levels of polyribosomes in zea mays in response to water stress. Plant Physiol. 1970;46(2):281-285. http://dx.doi.org/10.1104/pp.46.2.281

8. Mason HS, Mullet JE, Boyer JS. Polysomes, messenger RNA, and growth in soybean stems during development and water deficit. Plant Physiol. 1988;86(3):725-733. http:// dx.doi.org/10.1104/pp.86.3.725

9. Uesono Y. Transient inhibition of translation initiation by osmotic stress. J Biol Chem. 2002;277(16):13848-13855. http://dx.doi.org/10.1074/jbc.M108848200

10. Rhodes PR, Matsuda K. Water stress, rapid polyribosome reductions and growth. Plant Physiol. 1976;58(5):631-635. http://dx.doi.org/10.1104/pp.58.5.631

11. Slaymaker DH, Hoppey CM. Reduced polysome levels and preferential recruitment of a defense gene transcript into polysomes in soybean cells treated with the syringolide elicitor. Plant Sci. 2006;170(1):54-60. http://dx.doi. org/10.1016/j.plantsci.2005.07.026

12. Kawiak J, Mirecka J, Olszewska M, Warchoła J. Podstawy cytofizjologii. Warszawa: Polish Scientific Publishers PWN; 1997.

13. Davies E, Fillingham BD, Abe S, Ito Y. Polyribosomes from peas. VII. Initial characterization of a population of polysomes associated with the cytoskeleton. Cell Biol Int Rep. 1991;17:331-340.

14. Davies E, Fillingham B, Ito Y, Abe S. Evidence for the existence of cytoskeleton-bound polysomes in plants. Cell Biol Int Rep. 1991;15(10):973-981. http://dx.doi. org/10.1016/0309-1651(91)90147-B

15. Davies E. Intercellular and intracellular signals and their transduction via the plasma membrane-cytoskeleton interface. Semin Cell Biol. 1993;4(2):139-147. http://dx.doi. org/10.1006/scel.1993.1017

16. Hesketh JE, Pryme IF. Interaction between mRNA, ribosomes and the cytoskeleton. Biochem J. 1991;277:1-10.

17. Nicchitta CV, Lerner RS, Stephens SB, Dodd RD, Pyhtila B. Pathways for compartmentalizing protein synthesis in eukaryotic cells: the template-partitioning model. Biochem Cell Biol. 2005;83(6):687-695. http://dx.doi.org/10.1139/ o05-147

18. Adams A, Fey EG, Pike SF, Taylorson CJ, White HA, Rabin BR. Preparation and properties of a complex from rat liver of polyribosomes with components of the cytoskeleton. Biochem J. 1983;216(1):215-226.

19. Davies E, Abe S, Larkins BA, Clore AM, Quatrano RS, Weidner S. The role of the cytoskeleton in protein synthesis. In: Bailey-Serres J, Gallie DR, editors. A look beyond transcription: mechanisms determining mRNA stability and translation in plants. Rockville MD: Amer Society of Plant Physiologists; 1998. p. 115-124.

20. Weidner S, Łukaszewicz D, Amarowicz R. Significant role for polysomes associated with the cytoskeleton in the control of protein synthesis during germination of triticale caryopses in the presence of abscisic acid. Acta Physiol Plant. 2000;22(2):185-193. http://dx.doi.org/10.1007/ s11738-000-0075-5

21. Weidner S, Frączek E, Romanowska M, Amarowicz R, Abe S, Davies E. The influence of abscisic acid on different polysomal populations in embryonal tissue during pea seeds germination. Acta Physiol Plant. 2003;25(1):5-12. http://dx.doi.org/10.1007/s11738-003-0030-3

22. Abe S, Davies E. Isolation of F-actin from pea stems. Protoplasma. 1991;163(1):51-61. http://dx.doi.org/10.1007/ BF01323406

23. Bailey-Serres J. Selective translation of cytoplasmic mRNAs in plants. Trends Plant Sci. 1999;4(4):142-148. http:// dx.doi.org/10.1016/S1360-1385(99)01386-2

24. Hummel M, Rahmani F, Smeekens S, Hanson J. Sucrosemediated translational control. Ann Bot. 2009;104(1):1-7. http://dx.doi.org/10.1093/aob/mcp086

25. Gong P, Wilke BM, Strozzi E, Fleischmann S. Evaluation and refinement of a continuous seed germination and early seedling growth test for the use in the ecotoxicological assessment of soils. Chemosphere. 2001;44(3):491-500. http://dx.doi.org/10.1016/S0045-6535(00)00280-0

26. Davies E, Abe S. Methods for isolation and analysis of polyribosomes. Method Cell Biol. 1995;50:209-222. http:// dx.doi.org/10.1016/S0091-679X(08)61032-8

27. Abe S, Ito Y, Davies E. Co-sedimentation of actin, tubulin andmembranes in the cytoskeleton fractions from peas and mouse 3T3 cells. J Exp Bot. 1992;43(7):941-949. http:// dx.doi.org/10.1093/jxb/43.7.941

28. Bradford MM. A rapid and sensitive method for the quantitation of microgram quantities of protein utilizing the principle of protein-dye binding. Anal Biochem. 1976;72(1-2):248-254. http://dx.doi. org/10.1016/0003-2697(76)90527-3

29. Laemmli UK. Cleavage of structural proteins during the assembly of the head of bacteriophage T4. Nature. 1970;227(5259):680-685. http://dx.doi. org/10.1038/227680a0

30. Hamayuni M, Khan SA, Shinowari ZK, Khani AL, Ahmad N, Lee IJ. Effect of polyethylene glycol induced drought stress on physio-hormonal attributes of soybean. Pak J Bot. 2010;42:977-986.

31. Türkan I, Bor M, Özdemir F, Koca H. Differential responses of lipid peroxidation and antioxidants in the leaves of drought-tolerant P. acutifolius Gray and drought-sensitive $P$. vulgaris L. subjected to polyethylene glycol mediated water stress. Plant Sci. 2005;168(1):223-231. http://dx.doi. org/10.1016/j.plantsci.2004.07.032

32. Brosowska-Arendt W, Weidner S. Effect of osmotic stress on the formation of a population of polysomes and their stability in pea (Pisum sativum L.) seeds. Acta Physiol Plant. 2011;33(4):1475-1482. http://dx.doi.org/10.1007/ s11738-010-0686-4

33. Gill PK, Sharma AD, Singh P, Bhullar SS. Osmotic stressinduced changes in germination, growth and soluble sugar content of Sorghum bicolor (L.) moench seeds. Bulg J Plant Physiol. 2002;28:12-25.

34. Gomes FE, Eneas FJ, Tarquínio PJ. Effects of osmotic stress on growth and ribonuclease activity in Vigna unguiculata (L.) Walp. seedlings differing in stress tolerance. Rev Bras Fisiol Veg. 1996;8:51-57.

35. Khayatnezhad M, Gholamin R, Jamaati-e-Somarin S, Zabihi-e-Mahmoodabad R. Effects of peg stress on corn cultivars (Zea mays L.) at germination stage. World Appl Sci J. 2010;11:504-506.

36. Kosowska M, Frączek E, Amarowicz R, Karama M, Abe $\mathrm{S}$, Weidner S. Water-deficit-induced changes in cytoskeleton-bound and other polysomal populations in embryonic tissue during triticale caryopsis germination. Acta 
Physiol Plant. 2004;26(1):67-74. http://dx.doi.org/10.1007/ s11738-004-0046-3

37. Murillo-Amador B, Lopez-Aguilar R, Kaya C, Larrinaga-Mayoral J, Flores-Hernandez A. Comparative effects of nacl and polyethylene glycol on germination, emergence and seedling growth of cowpea. J Agron Crop Sci. 2002;188(4):235-247. http://dx.doi. org/10.1046/j.1439-037X.2002.00563.x

38. Kawaguchi R, Williams AJ, Bray EA, Bailey-Serres J. Waterdeficit-induced translational control in Nicotiana tabacum. Plant Cell Environ. 2003;26(2):221-229. http://dx.doi. org/10.1046/j.1365-3040.2003.00952.x

39. Klyachko N. Plant polysome binding to the actin cytoskeleton as a target for physiological regulation. Cell Biol Int. 2003;27(3):217-218. http://dx.doi.org/10.1016/ S1065-6995(02)00314-1

40. Abe S, Azama K, Sugimoto H, Davies E. Protein accumulation in the maize endosperm: role of polyribosomes and the cytoskeleton. Plant Physiol Biochem. 2003;41(2):125-131. http://dx.doi.org/10.1016/S0981-9428(02)00016-5

41. Klyachko N. Interaction of plant polysomes with the actin cytoskeleton. Cell Biol Int. 2000;24(6):351-358. http:// dx.doi.org/10.1006/cbir.1999.0517

42. Weidner S, Każarnowicz M, Frączek E, Amarowicz R, Karamać M. Exogenous abscisic acid increases stability of polysomes in embryos of triticale caryopses during germination. Acta Physiol Plant. 2006;28(6):627-634. http:// dx.doi.org/10.1007/s11738-006-0059-1

43. Dai H, Lo YS, Lin YH, Ruddat M, Chiang KS. In vitro polysome translation analysis of heat shock proteins in higher plants. Bot Bull Acad Sin. 1996;37:261-264.

44. Branco-Price C. Genome-wide analysis of transcript abundance and translation in arabidopsis seedlings subjected to oxygen deprivation. Ann Bot. 2005;96(4):647-660. http://dx.doi.org/10.1093/aob/mci217

45. Kawaguchi R, Girke T, Bray EA, Bailey-Serres J. Differential mRNA translation contributes to gene regulation under non-stress and dehydration stress conditions in Arabidopsis thaliana. Plant J. 2004;38(5):823-839. http://dx.doi. org/10.1111/j.1365-313X.2004.02090.x

46. Nicolai M. Large-scale analysis of mrna translation states during sucrose starvation in Arabidopsis cells identifies cell proliferation and chromatin structure as targets of translational control. Plant Physiol. 2006;141(2):663-673. http://dx.doi.org/10.1104/pp.106.079418

47. Shenton D. Global translational responses to oxidative stress impact upon multiple levels of protein synthesis. J Biol Chem. 2006;281(39):29011-29021. http://dx.doi. org/10.1074/jbc.M601545200

48. Perras M, Sarhan F. Polysome metabolism during cold acclimation in wheat. Plant Cell Physiol. 1990;31(8):1083-1089.

49. Morelli JK, Shewmaker CK, Vayda ME. Biphasic stimulation of translational activity correlates with induction of translation elongation factor 1 subunit [alpha] upon wounding in potato tubers. Plant Physiol. 1994;106(3):897903. http://dx.doi.org/10.1104/pp.106.3.897

50. Spriggs KA, Stoneley M, Bushell M, Willis AE. Reprogramming of translation following cell stress allows IRES-mediated translation to predominate. Biol Cell. 2008;100(1):27-38. http://dx.doi.org/10.1042/BC20070098

51. Morelli JK. Actin depolymerization affects stress-induced translational activity of potato tuber tissue. Plant Physiol. 1998;116(4):1227-1237. http://dx.doi.org/10.1104/ pp.116.4.1227 